\author{
Abstracta Iranica \\ Abstracta Iranica Revue bibliographique pour le domaine irano-aryen \\ Volume 37-38-39 | 2018 \\ Comptes rendus des publications de 2014-2016
}

\title{
Alexander Lubotsky. Alanic Marginal Notes in a Greek Liturgical Manuscript
}

Alexandre Perret

\section{(2) OpenEdition \\ 12 Journals}

\section{Electronic version}

URL: http://journals.openedition.org/abstractairanica/42982

DOI: 10.4000/abstractairanica.42982

ISBN: 1961-960X

ISSN: 1961-960X

Publisher:

CNRS (UMR 7528 Mondes iraniens et indiens), Éditions de l'IFRI

Electronic reference

Alexandre Perret, «Alexander Lubotsky. Alanic Marginal Notes in a Greek Liturgical Manuscript », Abstracta Iranica [Online], Volume 37-38-39 | 2018, document 5, Online since 30 December 2018, connection on 27 September 2020. URL : http://journals.openedition.org/abstractairanica/42982 ; DOI : https://doi.org/10.4000/abstractairanica.42982

This text was automatically generated on 27 September 2020

Tous droits réservés 


\title{
Alexander Lubotsky. Alanic Marginal Notes in a Greek Liturgical Manuscript
}

\author{
Alexandre Perret
}

\section{REFERENCES}

Alexander Lubotsky. Alanic Marginal Notes in a Greek Liturgical Manuscript. Vienna, Verlag der Österreichischen Akademie der Wissenschaften, 2015, 69 p. + 30 plates (Grammatica Iranica 2; Sitzungberichte der Philosophisch-historischen Klasse 859).

1 Work on the some thirty Alanic marginal notes in a 13th century Greek manuscript started around twenty-five years ago when Sysse Engberg studied this manuscript (Q12) in the library of the Academy of Sciences in St. Petersburg, and of which A. Lubotsky analyses the some thirty notes found in the margins in the study under review. In a short preface, he offers a very succinct overview of the language contacts of the Alans and of Alanic with the Greek Byzantine world, and describes the difficulties that the edition of the present study, originally planned as a cooperation, encountered.

2 Lubotsky then places the topic in perspective by the material analysis of the document, i.e. the manuscript itself, an Old Testament lectionary (Prophetologion), which at one point was owned and used by an Alanic priest who had learned to read and write Greek. This point is fundamental, for it reveals the adaptation of an Alanic language-speaking clergyman to his cultural and liturgical context, which testifies of strong links between the "Barbarian" communities and the Byzantine world - a phenomenon also pointed out in the same period by John Tzetzes' notes in the end of his Theogony.

Lubotsky therefore embeds the present Notes in a double approach, historic and linguistic, because the scribe made the translation of the most important Eastern Christian feasts' names from the Greek words into Alanic ones, among which are some morphological calques (e.g. "Chrysostomos" translated by "Zaerynkom", literally "golden mouth", referring to St John Chrysostom, one the most important Fathers of the Greek Church, whose liturgical feast takes place in January). The rest of the study 
consists in analyzing the Alanic glosses themselves, which is profits from previous research by Abaev (1935) and Bielmeier (1989) on Tzetzes' glosses. Lubotsky manages with a great dexterity to give a new focus on these latter, and to solve many of the phonologic problems due to the transcription into a Greek alphabet. It is very fortunate that most of the Alanic words analysed have a cognate in modern Ossetic dialects, which proves once more the direct filiation between both of these languages, and moreover their almost perfect identification.

4 Lubotsky finally offers in an appendix all the pages of manuscript Q12 within a few twenty pages, which allows the reader to discover by himself the acute difficulty the analysis faced, given that the glosses needed serious deciphering work.

5 It is to be hoped that other documents of this nature shall be discovered in Eastern Europe libraries, for them to testify of the Byzantine world's cultural and linguistic melting pot.

\section{AUTHORS}

\section{ALEXANDRE PERRET}

